\title{
Combined use of a femtosecond laser and a microkeratome in obtaining thin grafts for Descemet stripping automated endothelial keratoplasty: an eye bank study
}

\author{
Joaquim N. Murta ${ }^{1-3}$, Andreia M. Rosa ${ }^{1-3}$, Maria Joao C. Quadrado ${ }^{1-3}$, Ana D. Russo ${ }^{1}$, Sergio S. Brito , \\ Maria Fátima L. Silva ${ }^{4}$ \\ ${ }^{1}$ Ophthalmology Unit, Centro Hospitalar e Universitário de Coimbra \\ ${ }^{2}$ Centro Cirúrgico de Coimbra \\ ${ }^{3}$ Faculty of Medicine, University of Coimbra \\ ${ }^{4}$ Visual Neuroscience Laboratory, Institute of Biomedical Research on Light and Image, Faculty of Medicine, University of \\ Coimbra, Coimbra - Portugal
}

\begin{abstract}
Purpose: To evaluate the use of a femtosecond laser combined with a microkeratome in the preparation of posterior corneal disks for Descemet stripping automated endothelial keratoplasty (DSAEK). Methods: This experimental study involved ultrathin DSAEK tissue preparation of 22 donor corneas unsuitable for transplantation. The first cut was performed with an Intralase ${ }^{\circledR}$ FS60 laser and the second cut with a Moria CBm 300- $\mu$ m microkeratome. The thickness of the first cut was modified for each cornea to obtain a final graft thickness of less than $110 \mu \mathrm{m}$. Precut and postcut central pachymetry were performed with an ultrasonic pachymeter. Central endothelial cell density (ECD) was calculated before and 24 hours after tissue preparation.

Results: Final graft thickness was $105.0 \pm 26.1$ (SD) $\mu \mathrm{m}$ (range 65-117). The mean microkeratome head cut thickness was $324.5 \pm 10.9 \mu \mathrm{m}$ (range 310-345). Precut and postcut ECDs averaged $2250 \pm 222$ and $2093 \pm 286$ cells $/ \mathrm{mm}^{2}$, respectively, representing $6.9 \%$ of cell loss. No corneas were perforated.

Conclusion: Femtosecond FS60 lasers and Moria CBm 300- $\mu$ m microkeratomes can be used sequentially to prepare consistently thin DSAEK grafts with no irregular cuts or cornea perforations.
\end{abstract}

Keywords: DSAEK, Eye bank, Femtosecond, Thickness

Accepted: February 25, 2013

\section{INTRODUCTION}

Descemet stripping automated endothelial keratoplasty (DSAEK) has become the standard of care for Fuchs dystrophy and other causes of endothelial dysfunction (1). DSAEK consists of stripping a patient's diseased endothelium and replacing it with the healthy endothelium,
Descemet membrane, and a layer of stroma prepared from a donor cornea with an automated microkeratome $(2,3)$.

An important limitation of DSAEK is that some eyes do not achieve good visual acuity despite a clear cornea and minimal residual astigmatism (4-6). This may be caused by interface irregularity, the presence of donor posterior 
stroma, or a thick endothelial graft (7-9). The influence of endothelial graft thickness on visual acuity in DSAEK is controversial, with some authors reporting better results with thinner grafts and others finding no correlation (10-15). However, studies evaluating this subject have either focused on relatively thick grafts $(160-170 \mu \mathrm{m})$ or on grafts prepared by manual dissection (11-15). When grafts having less than $130 \mu \mathrm{m}$ are evaluated, a positive correlation between thickness and visual acuity is obtained $(9,10)$, suggesting that an effect may exist under a certain thickness. Obtaining thin grafts carries a higher risk of donor corneal perforation. Therefore, it is necessary to develop a technique to create thin posterior lamellar grafts without wasting donor corneas.
The present article presents a new technique that combines the sequential use of a femtosecond (FS) laser with a microkeratome to create posterior donor lenticules with a targeted thickness of less than $110 \mu \mathrm{m}$.

\section{MATERIALS AND METHODS}

This study was an institutional experimental laboratory investigation consisting of DSAEK tissue preparation on 22 human donor corneas. The corneas were unsuitable for transplantation due to positive donor serology results. Donor age and preservation to lamellar dissection time (storage time; see Tab. I) were recorded. Tissue was pre-

TABLE I - DONOR TISSUE DEMOGRAPHICS, DATA OBTAINED DURING EACH CUT, AND ENDOTHELIAL CELL DENSITY BEFORE AND 24 HOURS POSTCUT

\begin{tabular}{|c|c|c|c|c|c|c|c|c|c|}
\hline $\begin{array}{c}\text { Cornea } \\
\text { no. }\end{array}$ & Age, y & $\begin{array}{l}\text { Storage } \\
\text { time, d }\end{array}$ & $\begin{array}{c}\text { Initial } \\
\mathrm{CCT}, \mu \mathrm{m}\end{array}$ & $\begin{array}{l}\text { Programmed FS } \\
\text { cut thickness, } \mu \mathrm{m}\end{array}$ & $\begin{array}{l}\text { Intermediate } \\
\text { RSB, } \mu \mathrm{m}\end{array}$ & $\begin{array}{c}\text { Microkeratome } \\
\text { mean cut } \\
\text { depth, } \mu \mathrm{m}\end{array}$ & $\begin{array}{c}\text { Final } \\
\text { RSB, } \mu \mathrm{m}\end{array}$ & $\begin{array}{c}\text { Precut } \\
\text { ECD, } \\
\text { cells } / \mathrm{mm}^{2}\end{array}$ & $\begin{array}{l}\text { ECD } 24 \mathrm{~h} \\
\text { postcut, } \\
\text { cells } / \mathrm{mm}^{2}\end{array}$ \\
\hline 2 & 37 & 11 & 581 & 171 & 440 & 340 & 100 & 2222 & 1988 \\
\hline 3 & 75 & 10 & 530 & 120 & 430 & 314 & 116 & 2342 & 2604 \\
\hline 6 & 75 & 10 & 525 & 115 & 430 & 319 & 111 & 2227 & 1996 \\
\hline 7 & 37 & 11 & 570 & 160 & 430 & 315 & 115 & 2083 & 1838 \\
\hline 8 & 64 & 14 & 550 & 140 & 428 & 339 & 89 & 2597 & 2075 \\
\hline 9 & 52 & 10 & 530 & 120 & 427 & 341 & 86 & 2506 & 1919 \\
\hline 12 & 64 & 20 & 525 & 115 & 434 & 327 & 107 & 2141 & 2660 \\
\hline 13 & 49 & 3 & 535 & 125 & 428 & 313 & 115 & 2227 & 2653 \\
\hline 14 & 64 & 20 & 514 & 104 & 426 & 317 & 109 & 2506 & 2475 \\
\hline 15 & 49 & 16 & 550 & 140 & 428 & 322 & 106 & 2096 & 2041 \\
\hline 16 & 65 & 3 & 610 & 200 & 429 & 345 & 84 & 2053 & 2114 \\
\hline 17 & 42 & 5 & 588 & 178 & 431 & 334 & 97 & 2217 & 2045 \\
\hline 18 & 42 & 5 & 597 & 187 & 428 & 315 & 113 & 2193 & 2020 \\
\hline 19 & 74 & 7 & 580 & 170 & 427 & 315 & 112 & 2183 & 2299 \\
\hline 20 & 44 & 11 & 515 & 105 & 425 & 323 & 102 & 2882 & 1709 \\
\hline
\end{tabular}

$\mathrm{CCT}=$ central corneal thickness; $\mathrm{ECD}=$ endothelial cell density; FS = femtosecond; RSB = residual stromal bed. 


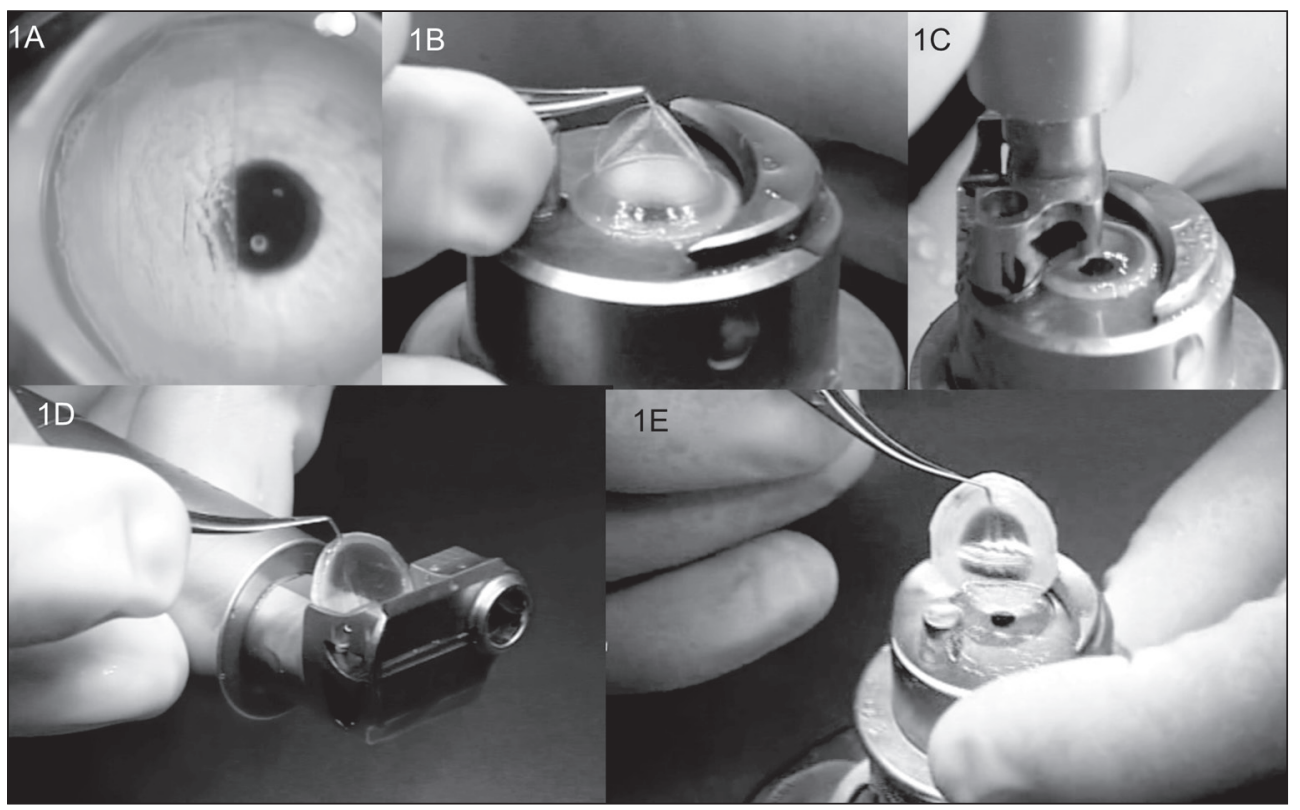

Fig. 1 - Donor cornea is assembled in an artificial anterior chamber and a first cut is performed with the femtosecond laser (1A). The thickness of this cut is chosen in order to leave approximately $410-430 \mu \mathrm{m}$ of intermediate residual stromal bed. The tissue is easily removed (1B). The second cut is performed with a 300- $\mu \mathrm{m}$ microkeratome head (1C, 1D) leaving a thin and smooth final residual stromal bed. The cornea is removed from the anterior chamber (1E).

served in Eusol-C ${ }^{\circledR}$ (Alchimia SRL, Padova, Italy) at a constant temperature of $4^{\circ} \mathrm{C}$ before use.

Each donor cornea had a 5-mm scleral rim and was mounted on an artificial anterior chamber (ALTK, Moria SA, Antony, France) filled with balanced salt solution (BSS ${ }^{\circledR}$, Alcon Laboratories, Fort Worth, Texas, USA). The BSS ${ }^{\circledR}$ bottle was elevated to $220 \mathrm{~cm}$ and the tubing was clamped at $60 \mathrm{~cm}$ from the anterior chamber, to ensure a high and stable anterior chamber pressure.

In order to obtain the initial central corneal thickness (CCT), precut central pachymetry was performed with an ultrasonic pachymeter (Corneo Gage Plus ${ }^{\circledR} 50$ MHz; Sonogage, Cleveland, Ohio, USA) after removal of the cornea epithelium. The first cut of the double-pass technique was performed with an Intralase ${ }^{\circledR}$ FS60 FS laser (Abbott Medical Optics, Santa Ana, California, USA), and the second cut with the Moria ${ }^{\circledR}$ CBm microkeratome $300 \mu \mathrm{m}$ cutting head (Moria SA, Antony, France) (Fig. 1). The programmed FS cut thickness of the first cut was calculated as follows:

Programmed FS cut thickness = initial CCT - (theoretical microkeratome cut thickness + desired final graft thickness) The theoretical microkeratome cut thickness was considered to be $300 \mu \mathrm{m}$ and the desired final graft thickness was $110 \mu \mathrm{m}$.

By replacing these values, this formula can be simplified as follows:

Programmed FS cut thickness = initial CCT $-410 \mu \mathrm{m}$.
Care was taken when positioning the donor tissue on the anterior chamber so that there was a regular ring of sclera appearing around the cornea. The FS cut was centered, having as reference the hole inside the anterior chamber, visible on the screen of the Intralase ${ }^{\circledR}$ (Fig. 1A). No suction ring was used and docking was straightforward. The FS settings were full lamellar cut with a diameter of $9.5 \mathrm{~mm}$, raster energy $1.5 \mu \mathrm{J}$, and anterior side cut at $90^{\circ}$ with $2.7 \mu \mathrm{J}$. A new applanation cone was used for each cornea. After laser passage, the disc of tissue was removed and central pachymetry was evaluated to obtain intermediate residual stromal bed thickness (Tab. I). The second cut was performed immediately afterward with the $300 \mu \mathrm{m}$ microkeratome head, keeping the manual rotation speed constant and with total duration of approximately 3-5 seconds. Central pachymetry was again repeated to obtain final residual stromal bed thickness. The tubing was unclamped with the BSS bottle at $150 \mathrm{~cm}$ to avoid turbulence inside the anterior chamber. Donor tissue was removed by gently pulling the scleral rim from the top of the anterior chamber and then immersed in the storage medium. Endothelial cell density was calculated before and 24 hours after the cuts, using a noncontact specular microscope (SP4000 noncontact specular microscope; Konan Medical Corp., Fair Lawn, New Jersey, USA). A technician marked the center of at least 50 endothelial cells and the computer software estimated the area and the cell density of the entire cornea. 


\section{RESULTS}

Donor age was $56.1 \pm 12.7$ years (mean $\pm \mathrm{SD}$ ) and preservation to lamellar dissection time was $10.5 \pm 4.6$ days. Death to preservation time was less than 12 hours in all cases. Initial CCT after epithelial debridement was $548.4 \pm 37.8 \mu \mathrm{m}$ (range 463-619 $\mu \mathrm{m}$; Tab. I). Cornea no. 5 (Tab. I) had an initial thickness of $463 \mu \mathrm{m}$, which would require a FS cut of $43 \mu \mathrm{m}$. This value is below the limit of the Intralase ${ }^{\circledast}$ depth range, which precluded cutting this cornea. The disc of tissue from the FS cut was easily removed in all cases.

Intermediate residual stromal bed was $429.7 \pm 3.2 \mu \mathrm{m}$. The microkeratome mean cut depth was $324.5 \pm 10.9 \mu \mathrm{m}$ (range 310-345 $\mu \mathrm{m}$; Tab. I). Final residual stromal bed was $105.1 \pm 10.2 \mu \mathrm{m}$ (range 84-119 $\mu \mathrm{m}$ ). Average precut endothelial cell density was $2250 \pm 222$ cells $/ \mathrm{mm}^{2}$ and postcut was $2093 \pm 286$ cells $/ \mathrm{mm}^{2}$, representing $6.97 \%$ cell loss. No corneas were lost due to perforation, irregular cuts, or buttonholes.

\section{DISCUSSION}

Despite excellent postoperative results, best-corrected visual acuity after DSAEK is sometimes less than that obtained with penetrating keratoplasty $(16,17)$. Several studies report that better results might be achieved with a smoother interface and thinner grafts $(2,9,10)$. Neff and colleagues (10) reported that grafts $\leq 131 \mu \mathrm{m}$ provided a statistically significant improvement in best-corrected visual acuity compared with thicker grafts. Several attempts have been made to develop a technique to create very thin DSAEK grafts, without wasting donor tissue (18-21).

A FS laser, without a microkeratome, was previously used for this purpose. However, the resulting surface was not as smooth as from a microkeratome and concentric folds would form due to compression or irregularity of the posterior stroma $(22,23)$. In addition, interface scatter may later appear (21).

The method we describe here, the double-pass technique, combines the sequential use of a FS laser and a microkeratome. The first pass is performed with the laser to avoid the variability of the microkeratome, but for the second cut the latter is used to obtain a smooth stromal bed (24). Posterior donor lenticules with a mean thickness of $105 \mu \mathrm{m}$ were obtained and no cornea was perforated. An important aspect of this technique is that the thinner cut is done first, leaving a strong and thick cornea for the microkeratome. Because the anterior stroma is the strongest (25), this approach avoids irregular cuts and buttonholes during the microkeratome cut.

The desired final graft thickness can be obtained by changing the parameters of the laser, which can be programmed to cut at a customized depth for each cornea, according to the initial pachymetry. This avoids using nomograms and allows having only one microkeratome head available, in this case a $300 \mu \mathrm{m}$, but other heads would probably work as well. It also has the advantage of using equipment already available in most cornea centers. The target thickness of $110 \mu \mathrm{m}$ was chosen essentially for safety reasons. This way, at least $410 \mu \mathrm{m}$ of corneal tissue are cut with a $300 \mu \mathrm{m}$ microkeratome head, minimizing the risk of perforation. Since the microkeratome we use usually cuts more than $300 \mu \mathrm{m}$ (26), we found that aiming for a final thickness of $110 \mu \mathrm{m}$ would actually result in thinner grafts (than $110 \mu \mathrm{m}$ ) without perforating. Because the microkeratome cut depth depends on several factors, such as intrachamber pressure, tissue thickness, and manual rotation speed, these factors are kept constant (tubing clamped at $60 \mathrm{~cm}$ when bottle is raised at $220 \mathrm{~cm}$, FS cut first, 3-5 seconds manual rotation speed) in order to reduce variability.

In terms of endothelial cell loss, the cut performed by the FS is superficial, similar to the flaps produced in laserassisted in situ keratomileusis (LASIK). Therefore, this cut should not induce any more cell loss than a regular LASIK flap. The second cut is performed immediately after the first to avoid further manipulation of the donor cornea. In the present study, mean endothelial cell loss from precut to 24 hours postcut was $6.9 \%$, which is higher than the 3\%-4\% reported by other authors $(22$, $26,27)$. However, the time interval between cutting the cornea and counting the cells is likely to be important when evaluating cell death, with longer intervals (as was the case in this study) being associated with lower final cell densities (28).

In conclusion, the technique described in this study combines the sequential use of a FS laser and a microkeratome to obtain posterior lamellar grafts with a mean thickness of $105 \mu \mathrm{m}$. More research is needed to determine the visual outcomes of this approach and to clarify whether there is an ideal graft thickness both in terms of visual recovery and endothelial cell loss. 


\section{ACKNOWLEDGMENT}

The authors thank Robert Van Velze for help in setting the parameters of this study.

Presented in part at the 2nd Eucornea Congress, Vienna, September 16-17, 2011, where it was awarded "Best Paper of Session"; and at the Association for Research in Vision and Ophthalmology, Fort Lauderdale, Florida, May 6-9, 2012, where it was selected for oral presentation.
The authors report no proprietary interest or financial support.

Address for correspondence:

Joaquim Neto Murta, MD, PhD

Ophthalmology Unit

Centro Hospitalar e Universitário de Coimbra

Praceta Mota Pinto

3000-075 Coimbra

Portugal

jmurta@netcabo.pt

\section{REFERENCES}

1. Lee WB, Jacobs DS, Musch DC, Kaufman SC, Reinhart WJ, Shtein RM. Descemet's stripping endothelial keratoplasty: safety and outcomes: a report by the American Academy of Ophthalmology. Ophthalmology 2009;116:1818-30.

2. Price MO, Price FW Jr. Descemet's stripping with endothelial keratoplasty: comparative outcomes with microkeratome-dissected and manually dissected donor tissue. Ophthalmology 2006;113:1936-42.

3. Gorovoy MS. Descemet-stripping automated endothelial keratoplasty. Cornea 2006;25:886-9.

4. Melles GR. Posterior lamellar keratoplasty: DLEK to DSEK to DMEK. Cornea 2006;25:879-81.

5. Dapena I, Ham L, Melles GR. Endothelial keratoplasty: DSEK/DSAEK or DMEK - the thinner the better? Curr Opin Ophthalmol 2009;20:299-307.

6. Mearza AA, Qureshi MA, Rostron CK. Experience and 12-month results of Descemet-stripping endothelial keratoplasty (DSEK) with a small-incision technique. Cornea 2007;26:279-83.

7. Chen ES, Terry MA, Shamie N, Hoar KL, Friend DJ. Descemetstripping automated endothelial keratoplasty: six-month results in a prospective study of 100 eyes. Cornea 2008;27: 514-20.

8. Ham L, Dapena I, van der Wees J, Melles GR. Secondary DMEK for poor visual outcome after DSEK: donor posterior stroma may limit visual acuity in endothelial keratoplasty. Cornea 2010;29:1278-83.

9. Pogorelov P, Cursiefen C, Bachmann BO, Kruse FE. Changes in donor corneal lenticule thickness after Descemet's stripping automated endothelial keratoplasty (DSAEK) with organcultured corneas. Br J Ophthalmol 2009;93:825-9.

10. Neff KD, Biber JM, Holland EJ. Comparison of central corneal graft thickness to visual acuity outcomes in endothelial keratoplasty. Cornea 2011;30:388-91.

11. Van Cleynenbreugel H, Remeijer L, Hillenaar T. Descemet stripping automated endothelial keratoplasty: effect of intraoperative lenticule thickness on visual outcome and endothelial cell density. Cornea 2011;30:1195-200.
12. Seery LS, Nau CB, McLaren JW, Baratz KH, Patel SV. Graft thickness, graft folds, and aberrations after Descemet stripping endothelial keratoplasty for Fuchs dystrophy. Am J Ophthalmol 2011;152:910-6.

13. Ahmed KA, McLaren JW, Baratz KH, Maguire LJ, Kittleson KM, Patel SV. Host and graft thickness after Descemet stripping endothelial keratoplasty for Fuchs endothelial dystrophy. Am J Ophthalmol 2010;150:490-7.

14. Shinton AJ, Tsatsos M, Konstantopoulos A, et al. Impact of graft thickness on visual acuity after Descemet's stripping endothelial keratoplasty. Br J Ophthalmol 2012;96:246-9.

15. Villarrubia A, Palacín E, Aránguez C, Solana J, García-Alonso CR. [Functional results after endothelial queratoplasty: three years of experience.] Arch Soc Esp Oftalmol 2011;86: 47-53.

16. Price FW Jr, Price MO. Descemet's stripping with endothelial keratoplasty in 200 eyes: early challenges and techniques to enhance donor adherence. J Cataract Refract Surg 2006;32:411-8.

17. Terry MA, Ousley PJ. Replacing the endothelium without corneal surface incisions or sutures: the first United States clinical series using the deep lamellar endothelial keratoplasty procedure. Ophthalmology 2003;110:755-64.

18. Busin M, Patel AK, Scorcia V, Ponzin D. Microkeratomeassisted preparation of ultrathin grafts for Descemet stripping automated endothelial keratoplasty. Invest Ophthalmol Vis Sci 2012;53:521-4.

19. Hsu M, Hereth WL, Moshirfar M. Double-pass microkeratome technique for ultra-thin graft preparation in Descemet's stripping automated endothelial keratoplasty. Clin Ophthalmol 2012;6:425-32.

20. Sikder S, Nordgren RN, Neravetla SR, Moshirfar M. Ultrathin donor tissue preparation for endothelial keratoplasty with a double-pass microkeratome. Am J Ophthalmol 2011; 152:202-8.

21. Hjortdal J, Nielsen E, Vestergaard A, Søndergaard A. Inverse cutting of posterior lamellar corneal grafts by a femtosecond laser. Open Ophthalmol J 2012;6:19-22.

22. Mootha VV, Heck E, Verity SM, et al. Comparative study of Descemet stripping automated endothelial keratoplasty 
donor preparation by Moria CBm microkeratome, horizon microkeratome, and Intralase FS60. Cornea 2011;30:320-4.

23. Jones YJ, Goins KM, Sutphin JE, Mullins R, Skeie JM. Comparison of the femtosecond laser (IntraLase) versus manual microkeratome (Moria ALTK) in dissection of the donor in endothelial keratoplasty: initial study in eye bank eyes. Cornea 2008;27:88-93.

24. Rosa AM, Neto Murta J, Quadrado MJ, et al. Femtosecond laser versus mechanical microkeratomes for flap creation in laser in situ keratomileusis and effect of postoperative measurement interval on estimated femtosecond flap thickness. J Cataract Refract Surg 2009;35:833-8.

25. Hamilton DR, Johnson RD, Lee N, Bourla N. Differences in the corneal biomechanical effects of surface ablation com- pared with laser in situ keratomileusis using a microkeratome or femtosecond laser. J Cataract Refract Surg 2008;34: 2049-56.

26. Kelliher C, Engler C, Speck C, Ward D, Farazdaghi S, Jun AS. A comprehensive analysis of eye bank-prepared posterior lamellar corneal tissue for use in endothelial keratoplasty. Cornea 2009;28:966-70.

27. Chen ES, Terry MA, Shamie N, Hoar KL, Friend DJ. Precut tissue in Descemet's stripping automated endothelial keratoplasty donor characteristics and early postoperative complications. Ophthalmology 2008;115:497-502.

28. Rose L, Briceño CA, Stark WJ, Gloria DG, Jun AS. Assessment of eye bank-prepared posterior lamellar corneal tissue for endothelial keratoplasty. Ophthalmology 2008;115:279-86. 